\title{
Brothers and barbarians: \\ Discursive constructions of 'refugees' in Russian media
}

\author{
Natalia Moen-Larsen
}

This article maps the unexplored terrain of representations of refugees in Russian media, using discourse theory and the concepts of subject positions and symbolic boundaries to analyse these representations. The research questions are: Who are the refugees? What discourses do they feature in? What kinds of symbolic boundaries do these representations maintain? This study analyses the three Russian newspapers Izvestija, Novaya gazeta and Rossiiskaya gazeta, focusing on how, between 1 January 2014 and 31 December 2015, these newspapers came to employ the term 'refugee' for persons from Ukraine and for those from the Middle East and North Africa (MENA). Analysis of the subject position of 'refugee' in discourses about security, humanitarianism, integration and nationalism reveals contrasting images of refugees from Ukraine and MENA refugees. The latter are represented as 'threatening' and 'alien': symbolic boundaries are maintained between Russians and these refugees as well as between 'superior' Russia and 'inferior' Europe. In contrast, refugees from Ukraine are often presented as similar to Russians. Nationalist discourse merges with security, humanitarian and integration discourses, creating contrasting symbolic boundaries between these two groups of refugees and Russians. Refugees are classed as 'preferred' or 'nonpreferred' migrants on the basis not of their situation, but their ethnicity.

Keywords: Refugees, Russia, discourse, subject position, symbolic boundaries

The number of refugees is increasing globally: by the end of 2015, some 65.3 million people were considered forcibly displaced (UNHCR, 2015: 2). In 2014, the Russian Federation was the largest single recipient of new asylum claims worldwide, mostly involving refugees from Ukraine, where the armed conflict had brought the total number of refugees in the Russian Federation up from 3,400 in 2012 to 231,800 (UNHCR, 2014: 10). Much scholarly work has been done on representations of refugees in Western news media, public and political discourses (e.g. Holzberg et al., 2018; Bocskor, 2018; Figenschou and Thorbjørnsrud, 2015; Cederberg, 2014), but Russian refugee representations remain largely unexplored. ${ }^{1}$ This article seeks to fill that gap through systematic examination of representations of 'refugees' in Russian news media.

I operate with a broad, empirically-driven definition of the term 'refugee': refugees are persons or groups of people who occupy the subject position 'refugee(s)' in a discourse. Drawing on discourse theory, I view 'refugee' as a floating signifier that can never be fully 
fixed in any particular discursive chain (Jørgensen and Phillips, 2002: 28). The analysis combines discourse theory and subject positions (Laclau and Mouffe, 2014), with symbolic boundaries (Lamont and Molnár, 2002) and boundary maintenance (Barth, 1969). In analysing how refugees were discursively constructed in Russian newspapers in the period 1 January 2014-31 December 2015, I examine subject positions - who the refugees are and in what discourses they appear - as well as the symbolic boundaries maintained by these representations.

The reason for using newsprint media as a source for data collection is twofold. Firstly, an analysis of newspapers gives access to representations of 'refugees' that circulate in Russia. Secondly, media representations are bearers of symbolic and persuasive power. The media cannot control people's actions, but may shape the minds of the public (Van Dijk, 1995: 10). Further, newspapers often feature national rhetoric that reinforces the "legitimate" identity of the citizen' by placing immigrants in the role of 'other' (Burroughs, 2015: 167). An analysis of newsprint media is therefore a fruitful way to explore the symbolic boundaries constructed and maintained by Russian refugee representations. Differing ways of presenting refugees have implications for public opinion about refugees and Russian refugee policy. Refugee representations demarcate identity options for those positioned as refugees, as well as identity options for Russians.

Representations of refugees in the Russian press cannot be analysed separately from Russia's historical and cultural context, and Russian discourses about migration in general. Russia takes part in international migration as a destination for many migrant workers from former Soviet Socialist Republics (Heusala and Aitamurto 2017). According to Stephen Hutchings and Vera Tolz (2015) Russia is currently prone to securitization of migration and "new racism', 'a prejudice based on a pseudo-rational hostility to alien customs and beliefs rather than biological difference'. A large body of literature documents the continuing rise of antiimmigrant sentiments, nationalism and xenophobia in Russian politics, media and society (e.g. Heusala and Aitamurto, 2017; Kolst $\varnothing$ and Blakkisrud, 2016; Hutchings and Tolz, 2015; Tolz and Harding, 2015; Moen-Larsen, 2014; Rulyova and Zagibalov, 2012; Schenk, 2012). Recently, anti-immigration campaigns have used Islam as a marker of migrant identity and a threat to Russian culture and security (Tolz and Harding, 2015). Russian politicians and state officials have been shown to distinguish between 'preferred' and 'non-preferred' migrants, 
with Belarussians and Ukrainians considered as part of the former category while Muslims from Central Asia are in the latter category (Abashin, 2017: 27, 31; Lassila 2017: 61-63).

Until 2014, Russia was not a major recipient of refugees, and is therefore different from other countries in Europe with a longer history of refugee reception. The majority of refugees in Russia come from Ukraine and are part of a 'preferred migrant' category. This merger of the categories 'preferred migrants' and 'refugees' makes Russia a particular case in European context. However, although the institution of refugee reception in Russia is different from other countries in Europe ${ }^{2}$ images of refugees also tend to cross national borders. Certain shared principles shape perceptions about insiders and outsiders, compatriots and foreigners across cultures.

Research of representations of immigrants and refugees in Western media has tended to focus on negative images. Teun A van Dijk (1995: 19) notes that immigration is often presented as an 'invasion' or a threatening 'wave', tacitly implying that refugees are actually 'economic refugees' and therefore 'fakes'. Leudar et al. (2008) argue representations of refugees and asylum seekers from the Middle East and Africa in the UK have been structured along 'hostility themes'. Others have connected refugee representations to a process of 'securitisation of migration', for example in the case of Chinese refugees in Canada (Ibrahim, 2005), and refugees from Middle East and North Africa (MENA) in Hungary (Thorleifsson, 2017; Bocskor, 2018). Such negative representations serve as arguments for excluding migrants and enforcing restrictive policies (e.g. Lueck et al., 2015; Bennett et al., 2013; Leudar et al., 2008). Studies have also found a humanitarian discourse for example in Greek (Lafazani, 2018) and Irish media (Burroughs, 2015) that positions refugees as victims in need of help. However, images of refugees as victims do not necessarily imply a right to protection. For example, Holzberg et al. (2018) argue that the German discourse of the refugee crisis frames asylum in terms of deservingness, rather than a legal right, and 'refugees continue to be racialized 'others' who have to prove that they are worthy of protection' (Holzberg et al., 2018: 547).

In sum, Russian and Western literature have found significant use of negative images and a tendency towards exclusion of migrants and refugees; however, there is also room for alternative representations, for example refugees as victims and migration as inevitable and necessary. In Russia, in recent years there has been a tendency to speak of certain groups of 
international migrants as more, or less, desirable - Slavs placed in the former group and Muslims in the latter. As I will show, this tendency is evident when Russian newspapers represent refugees from Ukraine as more civilised than refugees from the Middle East and North Africa (MENA). Moreover, most Western studies of refugee representations have concerned images of 'them' coming 'to us' - refugees from geographically or culturally distant locations, seeking asylum in the West. Russian refugee-representations, however, depict two simultaneous but quite different streams of refugees. This offers a unique opportunity to explore the dynamics of subject positioning and ethnic boundary maintenance, through analysis of similarities and contrasts between Russian representations of Ukrainian refugees and MENA refugees.

\section{Theoretical approach}

Fredrik Barth (1969) advocated the importance of investigating the social boundaries that define ethnic groups, not the 'cultural stuff' they enclose. The persistence of ethnic groups is dependent on boundary maintenance through expression and validation of group membership, involving identification of fellow members of ethnic group and dichotomisation of others as strangers. 'If a group maintains its identity when members interact with others, this entails criteria for determining membership and ways of signalling membership and exclusion' (Barth, 1969: 15). As an analytical concept, 'boundary' is well-suited for investigating any kind of group identity, not only analysis of ethnic groups. Michèle Lamont and Virág Molnár (2002: 168) call social boundaries 'symbolic' because they are 'conceptual distinctions made by social actors to categorize objects, people, practices, and even time and space... [such boundaries] separate people into groups and generate feelings of similarity and group membership' (ibid.). Discourses about migration articulate symbolic boundaries between insiders and outsiders, and construct perceptions about ethnic groups. In this article, I address boundary maintenance through a discourse analysis of refugee representation in Russian newspapers.

My analysis here is inspired by the discourse theory created by Ernesto Laclau and Chantal Mouffe, who see discourse as 'a structured totality from the articulatory practice' (2014: 91). An articulatory practice is 'any practice establishing a relation among elements' (ibid.). Speaking and writing are such articulatory practices. Being 'a structured totality', a discourse is more than one single statement: 'it is a thick grid of hundreds of statements that shape 
social reality' (Wilhelmsen, 2014: 63). For Laclau and Mouffe (2014: 101) 'the subject' is the same as subject positions in a discursive structure. Like other moments in discourse, subject positions are part of struggles over meaning. When different actors articulate contrasting representations of refugees they are taking part in struggles over the dominant - or hegemonic (Gramsci, 1978) - meaning of these subject positions. Identities are made up of multiple subject positions in different discourses and can be expressed and understood only through discourse (Davies and Harré, 2007: 262).

There is a fruitful connection between the concepts of 'subject positions' and 'symbolic boundaries'. Together they can shed light on the mechanisms involved when actors articulate an apparently similar subject position - refugee - in contrasting ways for different groups of people. By asking who the refugees are in Russian newspapers, I map the subject positions available to refugees in Russian discourses. By examining discourses where the subject position of refugee appears, I seek to show how different ways of speaking about refugees are part of boundary maintenance between groups, with differing policy implications. The literature on media coverage of refugees has found that refugees are sometimes represented as a security threat, fake or as victims (e.g. van Dijk 1995: 19; Leudar et. al., 2008) - three different ways of representing the subject position 'refugee' in discourse. Whereas subject position refers to a particular position in discourse, symbolic boundary highlights the relational aspect of subject positioning. To whom do the refugees pose a threat? Positioning refugees as threatening is a way of maintaining a boundary between insiders (Germans, Norwegians, Russians etc.) and outsiders (refugees).

In addition to discourses, subject positions and symbolic boundaries, I use moments and nodal points as analytical tools for structuring the analysis. Laclau and Mouffe (2014: 91) call the different positions within a discourse 'moments' and label privileged moments 'nodal points' which give meaning to other moments within a discourse (ibid: 99). For example, means of transportation, refugee routes, the reasons for leaving country of origin and refugee policies are all moments in discourses about refugees. But the moments that get included in one discourse are also dependent on the nodal points in this discourse. For instance, Islamic state and terrorism are nodal points in security discourse, the articles that connect refugees to terrorism also position them as security threats, other moments in security discourse are border controls, penalties, weapons and policing. According to discourse theory, meaning can never be permanently locked in one discourse; it is subject to flow and change. Thus, 
elements in a discourse are also 'floating signifiers': signs that different discourses are struggling to define (Jørgensen and Phillips, 2002: 28). Representations of refugees are such floating signifiers because refugees are positioned in contrasting ways in discourses about security, humanitarianism, integration and nationalism.

\section{Data and method}

Television is the main source of news in Europe, also in Russia (Hutchings and Tolz, 2015: 30). I have chosen to analyse newspapers articles for pragmatic reasons: their availability and the possibility to do word searches. According to Freedom House (2015), Russia lacks freedom of the press; Russian news media are part of the Kremlin's policy strategy, and the few remaining independent media outlets are constantly under threat of closure. In exploring how refugees are depicted in newsprint media, I treat Russian newspapers as channels that produce, reproduce and disseminate discourse.

The analysis builds on data from three Russian national newspapers - Izvestiya (Iz), Novaya gazeta $(N G)$ and Rossiiskaya gazeta $(R G)$, chosen because they have very different profiles. $I z$ is a pro-government broadsheet daily that publishes reports on current affairs in Russia and abroad, business, economy, and culture as well as comments and opinion pieces. $N G$, issued twice weekly, is one of the few remaining newspapers to challenge official positions and conduct investigative reporting. Finally, $R G$ is the official daily of the Russian government, authorized to be the first to publish information about new laws and executive enactments, thus presenting the government's official position. In April 2018, all three newspapers were rated among the five most influential Russian newspapers, based on the number of citations. ${ }^{3}$ I assume that their differing affiliations and positions will illustrate various meanings of 'refugee' within the field of discursivity.

In my data, $N G$ is an outlet for alternative articulations. Whereas $I z$ and $R G$ write of all the good that Russia does for Ukrainian refugees, and how the EU is failing when faced with MENA refugees, $N G$ commonly views Russia as a failing humanitarian actor unable to provide for refugees - Ukrainian or MENA. Due to space limitations, I have not been able to explore different voices and editorial choices here. The analysis focuses on the diversity of subject positions found in this rich empirical material. However, it is also important to acknowledge the presence of alternative representations. 
I base my discourse analysis on a large mass of texts: 1,146 newspaper articles - 264 from $I z$, 288 from $N G$ and 594 from $R G$ - downloaded from East View Information Services and Integrum World Wide. All three newspapers have online versions, but in order to delimit the empirical material I focus on their printed versions. The data sample consists of all texts that used the word 'refugee' in the period 1 January 2014-31 December 2015. I chose to limit the data to two years because I wanted to be able to read and analyse all the selected texts and map all available refugee representations. I preliminarily coded all articles and sorted the data manually before uploading the data in NVivo and developing a more elaborate coding scheme. I created the codes based on both deductive and inductive reasoning. Some codes had theoretical labels (e.g. subject position), while others emerged from repeated observations in the texts (e.g. geography, mobility, war). As a result, I focused the coding on two core points of reference:

1. Subject position (Who is the refugee - from where? a man/woman/child/elderly person? What other subject positions are synonyms for 'refugee'?) What other subject positions feature in the texts? (volunteers, soldiers, politicians etc.);

2. Context: What other moments are part of the story? (Main topic, location, transportation, refugee routes etc.) Which moments in the text are nodal points, and what discourses do they point to? ('Islamic state' and 'terrorism' are nodal points in security discourse; 'human welfare' and 'humanitarian aid' are nodal points in humanitarian discourse).

\section{Who are 'the refugees'?}

To answer the first research question and see who the refugees are in Russian newspapers I have sorted the empirical material according to the place of origin of refugees mentioned. (See Table 1.) In the data sample, 936 of 1,146 texts feature either refugees from Ukraine (576) or MENA refugees (360). In all three newspapers, references to the former dominate, while articles mentioning 'MENA refugees' outnumber articles addressing 'Other groups'. Thus, in the period 1 January 2014-31 December 2015, the subject position of refugee in $I z$, $N G$ and $R G$ was articulated mainly within two overarching discursive contexts - the crisis in Ukraine, and the refugee crisis in the Middle East, North Africa and Europe. Representations of 'refugee from Ukraine' and 'MENA refugee' are part of a struggle for being the dominant signified for the signifier 'refugee', the first image associated with the word 'refugee'. Figure 1 shows developments over time and the number of articles that mention refugees from 
Ukraine, MENA refugees and other groups, illustrating the struggle over the meaning of 'refugee' month by month.

Table 1. 'Refugee' in $I z, N G$ and $R G$, absolute numbers $(\mathrm{N})$ and percentages

* Note: 'Other groups': includes refugees from Chechnya in Europe; refugees in Russia and Europe during World War I and II; refugees from the Balkans; refugees from Palestine; refugees from Georgia (South Ossetia

\begin{tabular}{|c|c|c|c|c|c|c|c|c|}
\hline & \multicolumn{2}{|c|}{$I Z$} & \multicolumn{2}{|c|}{$N G$} & \multicolumn{2}{|c|}{$R G$} & \multicolumn{2}{|c|}{ SUM } \\
\hline & $\mathbf{N}$ & $\%$ & $\mathbf{N}$ & $\%$ & $\mathbf{N}$ & $\%$ & $\mathbf{N}$ & $\%$ \\
\hline Refugees from Ukraine & 151 & 57 & 141 & 49 & 284 & 48 & 576 & 50 \\
\hline MENA refugees & 76 & 29 & 81 & 28 & 203 & 34 & 360 & 32 \\
\hline Other groups ${ }^{*}$ & 37 & 14 & 66 & 23 & 107 & 18 & 210 & 18 \\
\hline SUM & 264 & 100 & 288 & 100 & 594 & 100 & 1146 & 100 \\
\hline
\end{tabular}

and Abkhazia) and Russians who apply for political asylum abroad.

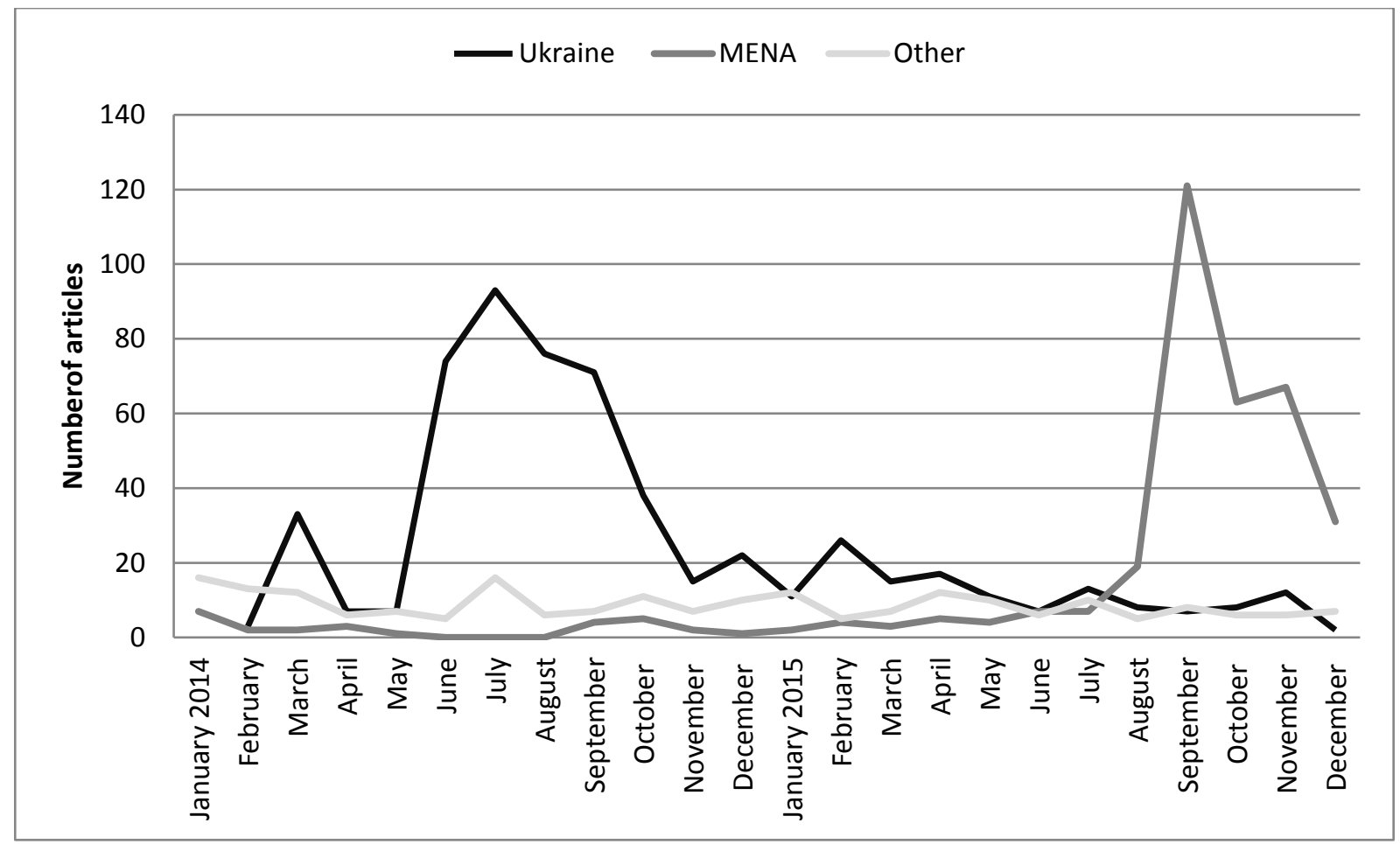

Figure 1. Development over time. Number of articles in the empirical material mentioning refugees from Ukraine, MENA refugees and other groups, 1 January 2014-31 December 2015.

Representations of refugees from Ukraine began appearing in February 2014, becoming most frequent in the period June-September 2014. In February 2014, the former president of 
Ukraine, Viktor Yanukovych, was ousted and fled to Russia. The escalation of violence in East Ukraine that followed the annexation of Crimea in March 2014 resulted in an outflow of refugees from Ukraine to Russia. This explains the first peak in Figure 1. Then, in the summer and autumn of 2015, many people from the Middle East and North Africa (MENA) tried to get to Europe by crossing the Mediterranean or Aegean Seas - some succeeding, others losing their lives on the way. Refugees and refugee crisis were hot topics in European mass media and politics in that period, so it is not surprising that MENA refugees featured also in Russian newspapers, as shown by the second peak in Figure 1.

In the period June-August 2014, when refugees from Ukraine dominated the newspapers, MENA refugees were not mentioned at all. However, Figure 1 shows how refugees from Ukraine gradually lost their hegemonic position as the main refugee-image in Russian newspapers, to be replaced by MENA refugees. Finally, Figure 1 shows the frequency of other refugee representations appearing in the data: their presence is quite low, thus supporting my choice of focusing on Ukraine and MENA refugees in the further analysis. In the following, I show how the meaning of 'refugee' is not given and fixed: it changes with context, as do the words that newspapers use to describe refugees.

\section{Discourse analysis}

I have identified two main discursive contexts that feature the subject position 'refugee': the crisis in Ukraine; and the refugee crisis in the Middle East, North Africa and Europe. We now turn to the second and third research questions, identifying discourses that represent refugees, and discussing symbolic boundaries constructed and maintained through those discourses. As it is impossible to present an exhaustive account of all discourses and subject positions present in the almost 1000 newspaper articles in the material, ${ }^{4} \mathrm{I}$ describe the dominant representations of refugees, illustrated with quotes from the data. ${ }^{5}$

Meticulous reading and coding of the data revealed four main discourses: security, humanitarian, integration and nationalist. These labels are in line with the literature on representations of refugees and migrants (e.g. Bocskor, 2005 on security; Rajaram, 2002 on humanitarianism; Hagelund, 2003: 161-217 on integration; Moen-Larsen, 2014 on nationalism). I argue that nationalist discourse merges with security, humanitarian and integration discourses and creates contrasting symbolic boundaries between MENA refugees, refugees from Ukraine and Russians. 


\section{Security Discourse}

Securitization of migration occurs when the migration discourse shifts to focus on security, and exclusion of migrants becomes legitimized by viewing them as a threat to the host society (Ibrahim, 2005; Bryan and Denov, 2011). The subject positions available to the refugee within the security discourse represent her or him as a danger and a threat. When actors articulate security discourse they construct symbolic boundaries between dangerous refugees and threatened selves and others. Barbarian, illegal and terrorist feature as synonyms for 'refugee'. Security discourse has the power to produce fear and therefore maintain symbolic boundaries between Russian readers and refugees - refugees are dangerous, deviant, and therefore unwanted. Although some articles represent refugees from Ukraine as a security threat to Russia(ns), ${ }^{6}$ the focus of security discourse in my data mainly concerns MENA refugees.

It is predominantly in stories where MENA refugees are connected to the nodal point Europe/EU ${ }^{7}$ that refugees become a dangerous 'force of nature' or a threatening 'wave'. For example, 'The stream of refugees has no end. Europe is in danger!' (Hungarian Prime Minister Victor Orban, quoted in $R G$, 7 September 2015). MENA refugees are represented as a destructive force that will bring about the demise of the EU. In security discourse, the goal of refugee policy is to restrict the mobility of refugees and control them. Physical boundaries, fences and walls are introduced as measures to block refugees from moving across the EU. Nevertheless, many articles note that the EU has proven powerless to stop MENA refugees.

The arrival of MENA refugees in the EU is sometimes presented as an invasion of barbarians. For example: 'Here in Russia the current wave of migration to Europe is imagined as a barbarian invasion of a civilization' (NG, 11 September 2015). In Russian - as in English barbarian connotes primitive, uncultured or uncivilized. Some authors point out that 'most of the barbarians intruding into Europe are young men' (Iz, 14 September 2015), aiming to conquer Europe and in the end to oust Europeans. 'In one generation Europeans will become a minority in Europe' (Iz, 8 September 2015). The nodal point Europe is constructed as a distinct civilization, and the arrival of refugees in Europe can be interpreted in line with Huntington's 'clash of civilizations' hypothesis (Huntington, 2002).

\section{Extract 1}


The collapse of Europe looks like this in figures: From the beginning of this year, the borders of united Europe have been crossed by more than 500000 illegals. Another two million are waiting for an opportunity [to go to Europe] in Turkey. (...) Hundreds of thousands of unregistered illegals have already crossed the EU borders, and remain unpunished. ( $R G, 16$ September 2015)

Both Russian and Western media occasionally represent migration as 'illegal' (Hutchings and Tolz, 2015; Burroughs, 2015). Arguably, representing refugees as illegal is also part of the securitization process: illegality implies that these persons are engaged in unlawful activity, and may be undesirable, perhaps dangerous. As Extract 1 shows, MENA refugees are represented as illegal because they have crossed EU borders without registration. Furthermore, in the context of security discourse, the large numbers of refugees signify a threat to Europe. The reference to unprotected EU borders contributes to the representation of a weak and victimised Europe.

Another representation of MENA refugees as threats is articulated when the refugee is linked to the nodal point 'terrorism'. Some articles claim that terrorists are infiltrating the EU posing as MENA refugees, for example:

\section{Extract 2}

A few months ago, NSA specialists broke the encrypted conversation of leaders of the 'Islamic State' and revealed that four terrorist groups have entered European countries as refugees. (Iz, 12 January 2015)

Many articles in the empirical material mention the Islamic State, its ideology and recruitment in refugee camps. While some articles construct insecurity based on the potential for terrorism in Europe, others link 'fake' refugees to actual terrorist attacks. For example: 'At least two of the terrorists who killed people on 13 November 2015 in Paris and Saint Denis infiltrated Europe posing as Syrian refugees' (NG, 9 December 2015). All subject positions are relational: because the EU is overwhelmed by large groups of refugees, refugees can remain unregistered and cross EU borders illegally - making it difficult to identify terrorists among the refugees. Not all MENA refugees are represented as terrorists, but the fact that some of them are spreads doubts about the motives of the whole group. Because security discourse has 
the potential to spread fear, it is a powerful way of constructing refugees as dangerous, and arguing against a liberal refugee policy.

\section{Humanitarian discourse}

Advocates of a humanitarian view on asylum emphasize that the state should protect persons whose security is under threat (Price, 2009: 4). The humanitarian discourse opens for asylum for people fleeing from violence, civil war or extreme poverty (ibid.). Scholars have criticized humanitarian discourse for reducing refugees to a-historical universal victims, blurring the 'individual politics and histories behind the pictures of teeming masses of bodies' (Rajaram 2002: 252). I do not claim that humanitarian discourse produces entirely positive images of refugees while security discourse does the opposite - both can be criticised. However, security discourse and humanitarian discourse position the refugees in ways that have differing policy implications. Within the frame of the security discourse, it becomes logical to argue for stricter border security and control of refugees. In humanitarian discourse, the focus turns to protection of human rights and provision of humanitarian aid. Russian newspapers articulate humanitarian discourse when human welfare is an important nodal point and when refugees are represented as victims - threatened, not threatening. They represent both MENA refugees and refugees from Ukraine as people fleeing from danger and death, conflicts and wars:

\section{Extract 3}

According to Konstantin Dolgov, the Russian Foreign Ministry's Commissioner for Human Rights, Democracy and the Rule of Law, the humanitarian situation in Ukraine is already comparable to that in Syria. 'Today we are counting hundreds of thousands of refugees, they are headed into the unknown, they are being fired on underway.' (Iz, 3 July 2014)

The humanitarian discourse positions refugees in relationships with humanitarian actors, like volunteers, aid providers and states that receive refugees. In this context, the nodal points 'Russia' and 'EU states' are articulated in contrasting and sometimes binary ways. Ideas about Europe as 'Other' have always been a part of Russian identity construction (Neumann, 2017), so it is not surprising to find that these ideas feature in Russian discourses about refugees. $I z$ and $R G$ claim that the EU is failing as a humanitarian actor and is unable to handle the inflow of refugees, due not least to poor cooperation within the Union: 'Meanwhile 
the EU heads, who have many times called for European solidarity, are unable to reach agreement on what to do with the stream of refugees that is growing every day' $(R G, 1$ September 2015). Images of a disintegrating EU feature in both humanitarian and security discourse in Russian newspapers. Whereas Europe is failing as a humanitarian actor, Russia is said to have handled the inflow of refugees in an exemplary matter:

\section{Extract 4}

We often hear criticism of our state and appeals to follow the example of European countries. But now all talk about a unified and prosperous Europe and common values has collapsed. And the reason for this is not a war, but 'merely' refugees. (...) In this context, it is useful to remember the situation in Russia in mid-2014 when the stream of refugees poured in from east Ukraine. (...) Our country has worked in an exemplary way: no one died, arrivals were provided with temporarily housing, were fed, medical assistance was provided to those who needed it. (Deputy Chairman of the State Duma, quoted in $R G, 21$ October 2015)

Articles about refugees from Ukraine often depict Russia as a successful humanitarian actor. They tell of the assistance provided by the government, regions, voluntary organisations and private individuals. Here, refugees from Ukraine are often represented as passive recipients of help - they are 'clothed, fed, given humanitarian aid' ( $R G, 9$ June 2014). Humanitarian discourse articulated in Russian newspapers focuses on representations of the EU and Russia, rather than offering detailed images of refugees as such. MENA refugees and refugees from Ukraine are moments in this discourse, represented through images of bodies, voiceless victims (Malkki, 1996; see also Rajaram, 2002), contributing to construct the EU as a failed humanitarian actor and Russia as a successful one. When newspapers articulate the humanitarian discourse in this way they also construct symbolic boundaries between the EU and Russia. That can have positive effects on Russians' attitudes towards refugees, as refugee reception is constructed as a competition with Europe and thus serves as an incentive to outdo Europe.

\section{Integration discourse}

'Integration' is a controversial term, the understanding and the use of which varies greatly (Aitamurto, 2017: 113; Kortmann, 2015: 1058-1016). Most Western European scholars agree 
that that integration is successful when immigrants participate in central societal institutions like the educational system and the labour market (Kortmann, 2015: 1060). Russian politicians understand integration as an aspect of cultural education, and use 'integration and adaptation of migrants' with reference to Russian society and values (Aitamurto, 2017: 115). My interpretation of integration is more in line with the use in Western scholarship. Integration stands 'for the variety of measures concerning immigrants' lives after the moment of immigration' (Hagelund, 2003: 161), and I use the term 'integration' as a label for a discourse that discusses such measures.

As in the humanitarian discourse, integration discourse adopts the humanitarian view that a refugee is someone in need of assistance. Humanitarian discourse places refugees in the process of transition from a state of crisis in the home country to a host society where they intend to apply for asylum or refugee status. Integration discourse takes over after arrival in the new country and after the host society has recognised them as refugees. Newspapers in my empirical material focus on integration of refugees from Ukraine because this discourse is particularly relevant for Russian readers - most refugees from Ukraine head for Russia. The representations of MENA refugees do not feature in the discussion in this section.

The sudden arrival of many newcomers represents a financial strain on state and regional budgets. It is essential to integrate them into society as quickly and smoothly as possible:

\section{Extract 5}

We take refugee reception very seriously (...) refugees from Ukraine are housed in sanatoriums, hostels, hotels; some of them are lodging with people who live alone. We want these people to be socialised as soon as possible and start working. We give them places in kindergartens and schools. (Senator of Bryansk oblast, quoted in Iz, 23 July 2015)

Extract 5 lists the integration measures that the Russian regions must address, and the nodal points in integration discourse articulated by Russian newspapers: housing, employment, education. Here, the subject positions available for refugees are employee and colleague, pupil, student. In line with Lassila (2017), I find that the newspapers often position employees from Ukraine as a potential resource for Russia - President Putin even called refugees from Ukraine 'petrol for the economy' ( $I z, 30$ March 2015). Some articles are optimistic about the 
inflow of specialists, for example claiming that ' $[\mathrm{t}]$ he shortage of doctors in rural areas will be solved by refugees from Ukraine' (Iz, 28 August 2014).

Education is another important nodal point in this integration discourse. The empirical material notes the need for places in kindergartens and schools for children from Ukraine, and the wish of young adult to study. Refugees from Ukraine are not represented as competitors to Russians. For example: "places in preschool institutions in municipalities where there is not a high demand for places in kindergartens may be offered to [children of refugees]' $(I z, 30$ July 2014, emphasis added). 'The education programs in Ukraine and Russia differ with regard to some subjects. We will consider this issue and help every child gain the missing knowledge (...) during the school year' (Iz 8 July 2014, emphasis added). The articles emphasize that children from Ukraine will not be competing with Russian peers over scarce places in kindergartens. Furthermore, they stress Russian education as superior to the education that pupils and students get in Ukraine.

Hegemonic representations of refugees from Ukraine in the context of integration have the power to produce positive attitudes towards them among Russian readers. Refugees are represented both as a potential resource for the Russian economy (in regions where qualified workers are scarce) and as not threatening the Russian population. The symbolic boundaries produced here subtly position refugees from Ukraine as inferior to Russians, but in a way that can strengthen the readers' willingness to receive and integrate refugees.

\section{Nationalist discourse}

The meaning of 'nationalism' is widely discussed. For instance, studies of Russian nationalism have distinguished between ethno-nationalism that emphasizes ethnic unity, and imperial nationalism that is nostalgic towards the imperial or Soviet past (Kolstø 2016; Pain 2016). Nationalist discourse constructs symbolic boundaries between Russians and refugees through a focus on cultural proximity. I argue that a nationalist discourse produces views of some ethnic groups as being more threatening than others, and influences how Russian newspapers position MENA refugees and refugees from Ukraine in connection with security, humanitarianism and integration. 
Ruth Wodak (2013) notes that writers reporting on immigration and religious differences often use 'culture' as an argument - culture is imagined as bounded and static, something that differentiates 'us' from 'them'. Russian newspapers use the nodal point 'culture' both to differentiate and to unify. A common representation of MENA refugees sees them as 'people from a different culture, who were brought up with completely other values' $(I z, 9$ November 2015). They are categorically different from Europeans and Russians. Other nodal points that contribute to the representation of MENA refugees as different are 'religion' and 'values'. Some articles position MENA refugees as representatives of a different civilization. This brings the analysis back to security discourse, and the representation of MENA refugees as a threat to Europe. MENA refugees are threatening because they are different. Europe is an arena of a tug-of-war between contrasting cultures, values and religions, and threatened with 'replacement of European civilization'. MENA refugees do not belong in Europe: they are 'aliens' who will ‘water down' European culture ( $R G, 31$ October 2014).

Also in representations of MENA refugees as victims of war in humanitarian discourse, the failure of EU to help them is a core moment. The refugees are unwanted in EU - but they are EU's responsibility. Such representations alienate Russian readers from MENA refugees. Nationalist discourse maintains a symbolic boundary between Russians and refugees by claiming that MENA refugees are categorically different from 'us' and by placing all responsibility for these refugees on the EU. In contrast, in writing about refugees from Ukraine, Russian newspapers position them as culturally close to Russians.

\section{Extract 6}

Our undisputable advantage in this situation was that these people [refugees from Ukraine] are from the same culture as us, they speak Russian, making adaptation easier [than for MENA refugees in Europe]. $(R G, 21$ October 2015)

Extract 6 is an example of a common representation of refugees from Ukraine as similar to Russians. The similarities are articulated as culture (and language). Sometimes, all differences between Russians and Ukrainians are completely erased: 'I do not distinguish between Ukrainians and Russians. In my opinion, they are one people' (Putin in Iz, 17 April 2015). While MENA refugees are depicted as members of an alien culture, refugees from Ukraine are seen as being like Russians. Indeed, some texts give Russianness as a reason why people had to leave Ukraine. For example: 'The [refugee] woman says that practically all the 
Russian-speaking population of Eastern Ukraine is today under the threat of annihilation by [Ukrainian] nationalists' ( $R G$, 5 March 2014). Furthermore, when Russian newspapers write about refugees from Ukraine they often use family metaphors: Ukrainians as brothers, Ukraine as fraternal country and the war in Ukraine as fratricidal war. For example, 'Today we are gathered to support our brothers in Ukraine, we are sincerely worried about their wellbeing and ready to help them - it is in our blood' (Governor of Krasnodar Oblast, quoted in $R G, 3$ March 2014).

Nationalist discourse tears down symbolic boundaries between Russian readers and refugees. When newspapers articulate nationalist discourse, and represent refugees from Ukraine as brothers, culturally similar to Russians or as Russian, that serves to legitimise their presence in Russia. This may explain the few representations of refugees from Ukraine as part of security discourse. Because refugees from Ukraine are the same as 'us', they are not a threat. Further, when humanitarian discourse introduces the view of refugees from Ukraine as victims of war, their cultural closeness works as an argument for helping them: 'it is in our blood'. Finally, the positioning of refugees as brothers suggests a smooth integration process. Because refugees are of the same culture, language and values, few extra measures are needed for them to be able to work or attend school in Russia.

\section{Concluding discussion}

This article has mapped the unexplored terrain of refugee representations in Russian newspapers, using discourse theory and the concepts of subject positions and symbolic boundaries to analyse these representations. Between 1 January 2014 and 31 December 2015, the three Russian newspapers studied here operated with two main refugee representations: refugee from Ukraine, and MENA refugee. Examination of subject positions in discourses about security, humanitarianism, integration and nationalism reveals contrasting images of refugees from Ukraine and MENA refugees. (See Table 2.) 
Table 2. Refugee representations in three Russian newspapers, 1 January 2014-31 December 2015: summary

\begin{tabular}{|c|c|c|c|c|}
\hline Discourse & Who? & Nodal points & $\begin{array}{l}\text { Subject positions } \\
\text { synonymous with } \\
\text { 'refugee' }\end{array}$ & Symbolic boundaries between \\
\hline Security & $\begin{array}{l}\text { Primarily } \\
\text { MENA } \\
\text { refugees }\end{array}$ & $\begin{array}{l}\text { The EU } \\
\text { Borders } \\
\text { Islamic State }\end{array}$ & $\begin{array}{l}\text { Barbarian } \\
\text { Illegal } \\
\text { Terrorist }\end{array}$ & $\begin{array}{l}\text { Russians and MENA refugees } \\
\text { Russia and the EU }\end{array}$ \\
\hline Humanitarian & $\begin{array}{l}\text { MENA } \\
\text { refugees } \\
\text { Refugees from } \\
\text { Ukraine }\end{array}$ & $\begin{array}{l}\text { Human welfare } \\
\text { Humanitarian aid } \\
\text { Humanitarian } \\
\text { actors }\end{array}$ & Victim & Russia and the EU \\
\hline Integration & $\begin{array}{l}\text { Primarily } \\
\text { refugees from } \\
\text { Ukraine }\end{array}$ & $\begin{array}{l}\text { Housing } \\
\text { Employment } \\
\text { Education }\end{array}$ & $\begin{array}{l}\text { Employee } \\
\text { Colleague } \\
\text { Pupil } \\
\text { Student }\end{array}$ & $\begin{array}{l}\text { Russians and refugees from } \\
\text { Ukraine }\end{array}$ \\
\hline Nationalist & $\begin{array}{l}\text { MENA } \\
\text { refugees } \\
\text { Refugees from } \\
\text { Ukraine }\end{array}$ & $\begin{array}{l}\text { Religion } \\
\text { Culture } \\
\text { Values }\end{array}$ & $\begin{array}{l}\text { MENA refugees as } \\
\text { aliens } \\
\text { Refugees from } \\
\text { Ukraine as brothers }\end{array}$ & $\begin{array}{l}\text { Russians and MENA refugees } \\
\text { Blurring the boundary between } \\
\text { refugees from Ukraine and } \\
\text { Russians }\end{array}$ \\
\hline
\end{tabular}

Combining the concepts of subject positions and symbolic boundaries has proven invaluable for illustrating the relational aspect of discursive positioning. The analysis has shown how different ways of positioning the refugee in discourses construct and maintain symbolic boundaries between groups. Within the nationalist discourse, for instance, a symbolic boundary is constructed between Russians and refugees, when MENA-refugees are positioned as someone with different culture and values, who does not belong in Europe. Nationalist discourse merges with security discourse to produce a dominant view of MENA refugees as a threat. In contrast, the newspapers position refugees from Ukraine as culturally and ethnically close to Russians, thereby legitimising the presence of refugees from Ukraine in Russia. The newspapers produce ideas about refugees from Ukraine as part of 'us' and 'our' responsibility, whereas MENA refugees are 'other' - and are the responsibility of 'others'. It is precisely these ideas that emerge when refugees from Ukraine are called 'brothers' and MENA refugees are labelled 'barbarians'. Furthermore, when MENA refugees are positioned as threats in the security discourse, that feeds the idea of the EU as weak and threatened, and of Russia as superior to the EU. 
All texts can be considered as instances of the use of power 'in which writers act as governing subjects vis-à-vis readers, who become objects of the power' (Autto and Törrönen, 2017: 65). The authors of the texts analysed here attempt to shape the readers' understanding of refugees and gain their support for certain policies. In 2014-2015, it seemed unlikely that the Russian public would be mobilised in support of asylum for MENA refugees, whereas $81 \%$ of Russians surveyed were positive towards receiving refugees from south-eastern Ukraine in July 2014 (Levada-Center, 2014). However, the attitudes of Russians towards Ukrainians have shifted over time. In a report on xenophobic sentiments in Russia, Pipiya (2018) documents an increase in negative attitudes to migrants from Ukraine. For example, the percentage of respondents who said they did not want to see Ukrainians in Russia has increased from $13 \%$ in 2010 to $22 \%$ in 2018. Possible reasons for this change in public opinion may include the negative coverage of events in Ukraine and the Kremlin's demonization of the Ukrainian government as 'fascist' (Alexeev and Hale 2016: 208). Systematic study of post-2015 representations of refugees from Ukraine goes beyond the scope of this article, but should be the focus of future studies.

This analysis has focused on representations of refugees in Russian newspapers, but that does not mean that the mechanisms explored here are exclusively Russian. Also elsewhere, the process of articulation of subject positions in specific ways contributes to the construction and maintenance of symbolic boundaries between groups. When we speak of people as 'compatriots' we usually also treat them as such - likewise for 'aliens'. Social constructs like these come with a prescribed treatment plan: victims need to be helped, the sick need healthcare, children should attend school, adults should work and serve as a resource whereas terrorists should be neutralised and criminals incarcerated. Such social constructions enable policies and practices. Our perceptions about refugees play a part in determining their opportunities and limitations in our society. Future research should study representations of refugees comparatively in different cultural contexts, asking whether and why some groups are ranked as 'worthier' than others, and what kind of group boundaries such representations maintain. Answers to these questions may bring out contrasting ideas about refugees that underlie disagreements about refugee policy, not least within the EU. 


\section{Acknowledgements}

I thank the editors and the anonymous reviewers whose comments have greatly improved this article. I am also grateful to Anne Krogstad and Helge Blakkisrud for their valuable guidance and advice.

\section{Notes}

${ }^{1}$ There are some recent studies of Russian refugee representations, for example Braghiroli and Makarychev (2017) explore Russian representations of 2015 refugee crisis, focusing on geopolitics, and Lassila (2017) discusses the representation of Ukrainian refugees in Russian political discourse.

${ }^{2}$ In 1993 Russia adopted its Federal Law on Refugees and established the Federal Migration Service (FMS). In 2016 FMS was replaced by the General Administration for Migration Issues of the Interior Ministry of Russia. In June 2017 Russia had 187,785 temporary asylum holders and 587 individuals with refugee status; only 2294 temporary asylum holders and 410 individuals with refugee status had non-Ukrainian background (UNHCR, 2018: 1-2). These figures are relatively low. For example, in Norway, with a population of only 5.3 million, there were 228,161 people with refugee background in 2018 (Statistics Norway, 2018). Ukrainian refugees in Russia enjoy a simplified migration regime not available to nonUkrainian refugees. The main challenges for non-Ukrainian refugees in Russia are 'hindered access to the territory, non-admission or hampered access to the asylum procedure, growing rejection rates of persons of concern to UNHCR and lack of integration opportunities for TA [temporary asylum] holders and recognized refugees' (UNHCR, 2018: 2).

${ }^{3}$ Available at: http://www.mlg.ru/ratings/media/federal/4748/\#gazeti. Accessed 25 April 2018.

${ }^{4}$ Refugee representations excluded from this analysis because of space limitations included issues connected to ideas about homeland, mobility, health, history, war, economy, politics, popular and high culture.

${ }^{5}$ All citations of Russian media statements were translated by the author.

${ }^{6}$ Some articles mention illegals from Ukraine, people who cross the border from Ukraine illegally or take part in criminal activities. Other articles write about Ukrainian militants who crossed the Russian border posing as refugees.

${ }^{7}$ Russian newspapers do not distinguish between the EU and Europe, but use these terms interchangeably; I will follow this (technically incorrect) practice in the analysis here.

\section{Biographical note}

Natalia Moen-Larsen is a doctoral research fellow at the Department of Sociology and Human Geography at the University of Oslo. In her PhD project she examines the discursive construction of 'refugees' in the Russian context. Moen-Larsen also does research on migration, inter-ethnic tensions and nationalism. 


\section{References}

Abashin S (2017) Migration policies in Russia. Laws and debates. In: Heusala A and Aitamurto K (eds) (2017) Migrant Workers in Russia. Global Challenges of the Shadow Economy in Societal Transformation. London: Routledge, pp. 16-34.

Aitamurto K (2017) Religion and the integration of migrants. In: Heusala A and Aitamurto K (eds) (2017) Migrant Workers in Russia. Global Challenges of the Shadow Economy in Societal Transformation. London: Routledge, pp. 110-127.

Alexseev MA and Hale HE (2016) Rallying round the leader more than the flag: Changes in Russian nationalist public opinion 2013-2014. In: Kolstø P and Blakkisrud H (eds) (2016) The New Russian Nationalism: Imperialism, Ethnicity and Authoritarianism 2000-15. Edinburgh: Edinburgh University Press, pp. 192-220.

Autto JM and Törrönen J (2017) Justifications of citizens' subject positions in public debates on welfare. Acta Sociologica 60(1): 61-73.

Barth F (1969) Ethnic Groups and Boundaries: The Social Organization of Culture Difference. Oslo: Universitetsforlaget.

Bennett S, ter Wal J, Lipiński A, Fabiszak M and Krzyżanowski M (2013) The representation of third-country nationals in European news discourse. Journalism Practice 7(3): 248-65.

Bocskor A (2018) Anti-Immigration Discourses in Hungary during the 'Crisis' Year: The Orbán Covernment's 'National Consultation’ Campaign of 2015. Sociology 52(3) 551-68.

Braghiroli S and Makarychev A (2017): Redefining Europe: Russia and the 2015 refugee crisis. Geopolitics, DOI: 10.1080/14650045.2017.1389721

Bryan C and Denov M (2011) Separated refugee children in Canada: The construction of risk identity. Journal of Immigrant \& Refugee Studies 9(3): 242-66.

Burroughs E (2015) Discursive representations of 'illegal migration' in the Irish newsprint media: The domination and multiple facets of the 'control' argumentation. Discourse and Society 26(2): 165-83.

Cederberg M (2014) Public Discourses and migrant stories of integration and inequality: language and power in biographical narratives. Sociology 48(1) 133-149.

Crowe M (2000) Constructing normality: A discourse analysis of the DSM-IV. Journal of Psychiatric and Mental Health Nursing 7(1): 69-77.

Davies B and Harré R (2007) Positioning: The discursive production of selves. In: Wetherell M, Taylor S, Yates SJ (eds) Discourse Theory and Practice. London: Sage, pp. 261- 283.

Don ZM and Lee C (2014) Representing immigrants as illegals, threats and victims in Malaysia: Elite voices in the media. Discourse and Society 25(6) 687-705. 
Figenschou TU and Thorbjørnsrud K (2015) Faces of an invisible population. Human interest framing of irregular immigration news in the United States, France, and Norway. American Behavioral Scientist 59(7): 783-801.

Freedom House (2015) Freedom of Press: Russia. Available at https://freedomhouse.org/report/freedom-press/2015/russia. (accessed 23 December 2015).

Gramsci A (1978) Selections from the Prison Notebooks. London: Lawrence.

Hagelund A (2003) The Importance of Being Decent: Political Discourse on Immigration in Norway 1970-2002. Oslo: Unipax Institutt for samfunnsforskning.

Heusala A and Aitamurto K (eds) (2017) Migrant Workers in Russia. Global Challenges of the Shadow Economy in Societal Transformation. London: Routledge.

Holzberg B, Kolbe K and Zaborowski R (2018) Figures of Crisis: The Delineation of (Un)Deserving Refugees in the German Media. Sociology 52(3) 534-50.

Huntington SP (2002) The Clash of Civilizations and the Remaking of World Order. London: The Free Press.

Hutchings S and Tolz V (2015) Nation, Ethnicity and Race on Russian Television: Mediating Post-Soviet Difference. London: Routledge.

Ibrahim M (2005) The securitization of migration. A racial discourse. International Migration 43(5): $163-87$.

Jørgensen M and Phillips, L (2002) Discourse Analysis as Theory and Method. London: Sage.

Kolstø P (2016) Introduction: Russian nationalism is back - but precisely what does that mean? In: Kolst $\varnothing$ P and Blakkisrud H (eds) (2016) The New Russian Nationalism:

Imperialism, Ethnicity and Authoritarianism 2000-15. Edinburgh: Edinburgh University Press, pp. 1-17.

Kolst $\varnothing$ P and Blakkisrud H (eds) (2016) The New Russian Nationalism: Imperialism, Ethnicity and Authoritarianism 2000-15. Edinburgh: Edinburgh University Press.

Kortmann M (2015) Asking those concerned: How Muslim migrant organisations define integration. A German-Dutch comparison. Journal of International Migration and Integration 16: 1057-80.

Laclau E and Mouffe C (2014) Hegemony and Socialist Strategy. Towards a Radical Democratic Politics. London: Verso.

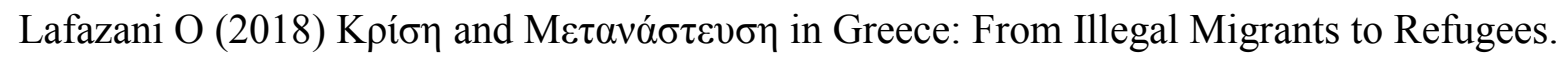
Sociology 52(3) 619-25.

Lamont M and Molnár V (2002) The study of boundaries in social sciences. Annual Review of Sociology 28: 167-95. 
Lassila J (2017) Beyond conjunctures of Russia's national future. Migrants and refugees in Russia's political discourse in 2013 and 2014. In: Heusala A and Aitamurto K (eds) (2017) Migrant Workers in Russia. Global Challenges of the Shadow Economy in Societal Transformation. London: Routledge, pp. 51-69.

Leudar I, Hayes J, Nekvapil J and Baker JT (2008) Hostility themes in media, community and refugee narratives. Discourse and Society 19(2): 187-221.

Levada-Center (2014) Rossiyane o bezhentsah. Available at www.levada.ru/2014/08/05/rossiyane-o-bezhentsah/ (accessed 13 April 2017).

Lueck K, Due C and Augoustinos M (2015) Neoliberalism and nationalism: Representations of asylum seekers in the Australian mainstream news media. Discourse and Society 26(5): 608-29.

Malkki LH (1996) Speechless emissaries: refugees, humanitarianism, and dehistoricization. Cultural Anthropology 11(3): 377-404.

Moen-Larsen N (2014) 'Normal nationalism': Alexei Navalny, LiveJournal and 'the Other'. East European Politics 30(4): 548-67.

Neumann IB (2017) Russia and the Idea of Europe. A Study in Identity and International Relations, $2^{\text {nd }}$ edn. London: Routledge.

Pain E (2016) The imperial syndrome and its influence on Russian nationalism. In: Kolstø P and Blakkisrud H (eds) (2016) The New Russian Nationalism: Imperialism, Ethnicity and Authoritarianism 2000-15. Edinburgh: Edinburgh University Press, pp. 46-74.

Pipiya K (2018) Monitoring ksenofobskih nastroenii, iyul' 2018 goda. Available at https://www.levada.ru/2018/08/27/monitoring-ksenofobskih-nastroenij/ (accessed 5 September 2018).

Price ME (2009) Rethinking Asylum: History, Purpose, and Limits. Cambridge: Cambridge University Press.

Rajaram PK (2002) Humanitarianism and representations of the refugee. Journal of Refugee Studies 15(3): 247-64.

Rulyova N and Zagibalov T (2012) Blogging the Other: Construction of national identities in the blogosphere. Europe-Asia Studies 64(8): 1524-45.

Schenk C (2012) Nationalism in the Russian media: content analysis of newspaper coverage surrounding conflict in Stavropol, 24 May-7 June 2007. Nationalities Papers 40(5): 783-805.

Statistics Norway (2018) Innvandrere. Available at https://www.ssb.no/innvandring-oginnvandrere/faktaside/innvandring\#blokk-5 (accessed 23 October 2018).

Thorleifsson C (2017) Disposable strangers: far-right securitisation of forced migration in Hungary. Social Anthropology 25(3): 318-334. 
Tolz V and Harding S (2015) From 'compatriots' to 'aliens': the changing coverage of migration on Russian television. The Russian Review 74: 452-77.

UNHCR (2014) Global Trends. Forced Displacement in 2014. Available at http://www.unhcr.org/statistics/country/556725e69/unhcr-global-trends-2014.html (accessed 15 February 2017).

UNHCR (2015) Global Trends. Forced Displacement in 2015. Available at http://www.unhcr.org/statistics/unhcrstats/576408cd7/unhcr-global-trends-2015.html (accessed 15 February 2017).

UNHCR (2018) UNHCR Submission on Russian Federation: 30th UPR session. Available at http://www.refworld.org/country,,UNHCR,,RUS,,5b082dbf4,0.html (accessed 23 October 2018).

Van Dijk TA (1995) Power and the news media. In: Paletz D (ed) Political Communication and Action. Cresskill, NJ: Hampton Press, pp. 9-36.

Wilhelmsen J (2014) How War Becomes Acceptable: Russian Rephrasing of Chechnya. PhD Dissertation, Department of Political Science, University of Oslo.

Wodak R (2013) 'Anything goes': The Haiderization of Europe. In: Wodak R, Khosravinik M and Mral B (eds) Right-Wing Populism in Europe: Politics and Discourse. London:

Bloomsbury, pp. 23-38. 